15. Tagusari O, Ogino H, Kobayashi J, Bando K, Minatoya K, Sasaki H, et al. Should the transverse aortic arch be replaced simultaneously with aortic root replacement for annuloaortic ectasia in Marfan syndrome? J Thorac Cardiovasc Surg. 2004; $127: 1373-80$.

16. Ince H, Rehders TC, Petzsch M, Kische S, Nienaber CA. Stent-grafts in patients with Marfan syndrome. J Endovasc Ther. 2005;12:82-8.

17. Marcheix B, Rousseau H, Bongard V, Heijmen RH, Nienaber CA, Ehrlich M, et al. Stent grafting of dissected descending aorta in patients with Marfan's syndrome mid-term results. JACC Cardiovasc Interv. 2008;1: 673-80.

18. Akin I, Kische S, Rehders TC, Chatterjee T, Schneider H, Korber T, et al. Current role of endovascular therapy in Marfan patients with previous aortic surgery. Vasc Health Risk Manag. 2008;4:59-66.

19. Langer S, Mommertz G, Koeppel TA, Schurink GW, Autschbach R, Jacobs MJ. Surgical correction of failed thoracic endovascular aortic repair. J Vasc Surg. 2008;47:1195-202.
20. LeMaire SA, Carter SA, Volguina IV, Laux AT, Milewicz DM, Borsato GW, et al Spectrum of aortic operations in 300 patients with confirmed or suspected Marfan syndrome. Ann Thorac Surg. 2006;81:2063-78.

21. Crawford ES, Coselli JS, Svensson LG, Safi HJ, Hess KR. Diffuse aneurysmal disease (chronic aortic dissection, Marfan, and mega aorta syndromes) and multiple aneurysm. Treatment by subtotal and total aortic replacement emphasizing the elephant trunk operation. Ann Surg. 1990;211:521-37.

22. LeMaire SA, Carter SA, Coselli JS. The elephant trunk technique for staged repair of complex aneurysms of the entire thoracic aorta. Ann Thorac Surg. 2006 81:1561-9.

23. Safi HJ, Miller CC III, Estrera AL, Huynh TT, Rubenstein FS, Subramaniam MH et al. Staged repair of extensive aortic aneurysms: morbidity and mortality in the elephant trunk technique. Circulation. 2001;104:2938-42

24. Pichlmaier MA, Teebken OE, Khaladj N, Weidemann J, Galanski M, Haverich A. Distal aortic surgery following arch replacement with a frozen elephant trunk. Eur J Cardiothorac Surg. 2008;34:600-4.

\title{
COMMENTARY
}

\section{The can-should problem}

\author{
Thoralf M. Sundt III, MD
}

For as this ought, or ought not, expresses some new relation or affirmation, 'tis necessary that it should be observed and explained; and at the same time that a reason should be given ... how this new relation can be a deduction from others, which are entirely different from it.

David Hume, A Treatise of Human Nature, 1739

The place of endovascular stent grafting in the treatment of Marfan syndrome remains unclear; for that matter, so is the place of endovascular stent grafting in acute dissection. Accordingly, the data presented in this study are of interest to the cardiovascular surgical community. Despite "expert consensus" that stent grafts should not be used in patients with connective tissue disorders, we are all seeing more patients in whom they have been used either in ignorance of the underlying condition or in emergency salvage conditions. The morbidity associated with descending thoracic and thoracoabdominal aortic aneurysm disease occurring as a late sequela of dissection is driving application of the "frozen elephant trunk" operation. These authors have ex-

\footnotetext{
From the Division of Cardiac Surgery, Massachusetts General Hospital, Boston, Mass.

Address for reprints: Thoralf M. Sundt III, MD, Edward D. Churchill Professor and Chair, Division of Cardiac Surgery, Massachusetts General Hospital, 55 Fruit St, Boston, MA 02114 (E-mail: tsundt@partners.org).

J Thorac Cardiovasc Surg 2011;142:e91

$0022-5223 / \$ 36.00$

Copyright (c) 2011 by The American Association for Thoracic Surgery

doi:10.1016/j.jtcvs.2011.04.002
}

plored both and conclude "that this procedure is feasible." The question, of course, is whether it is advisable.

The authors have followed 44 Marfan patients with acute $(n=19)$ or chronic $(n=25)$ dissection. Short-term results were acceptable; importantly, there were no instances of paraplegia. Follow-up, however, was only $38 \pm 17$ months. During this period there were 2 deaths and 1 patient required thoracoabdominal aortic replacement. Computed tomographic scanning demonstrated thrombosis around the stent graft, but below that level in only $45 \%$. Furthermore, aortic enlargement - the result of true interest-occurred in 3 of the 19 patients with acute dissection and 6 of the surviving 23 patients with chronic dissection. The stent graft extended into the false lumen in 4 of those with acute dissection. The question is, then, is this success?

One runs the risk of appearing a Luddite when criticizing the use of novel technology. And, of course, it is always more comfortable to sit in the camp of conventional wisdom while another has the courage to challenge dogma. It is not my aim to impune the authors' efforts to advance the treatment of this challenging group of patients. We do, however, need to draw a distinction between therapy that should be considered "experimental" and most appropriate in the setting of a carefully monitored prospective study, and a new standard of care. What is apparent is that we can perform this procedure. What remains unknown is whether we should. 